Araştırma Sunumu|Research Article

\title{
IL7R GEN MUTASYON VE POLIMMORFIZMLARİNIN AĞIR KOMBİNE İMMUN YETMEZLİKLİ HASTALARDAKİ SIKLIĞI
}

\section{The frequency of IL7R Gene Mutation and Polymorphisms in Severe Combined Immunodeficiency patients}

\author{
Atıl Bişgin \\ Çukurova Üniversitesi, abisgin@yahoo.com \\ İbrahim Boğa \\ Çukurova Üniversitesi, ibr.boga@gmail.com \\ Mustafa Yılmaz \\ Çukurova Üniversitesi, dryilmazm@gmail.com \\ Derya Ufuk Altıntaş \\ Çukurova Üniversitesi, deryaufuk@gmail.com
}

Öz

Ağır kombine immün yetmezlik immün sistem hücrelerinin defektleri ile ilgili olan nadir görülen genetik bir hastalıktır. Bu hastalık T lenfosit, B lenfosit ve Doğal Öldürücü (NK) lenfosit gruplarının birinde veya birkaçında görülebilir. Çalışmamızda Türkiye'nin güneyinde yer alan ağır kombine immün yetmezlikli hastalarda interlökin 7 reseptörü gen polimorfizmlerinin tanımlanması ve hastaların immünfenotip sonuçları ile birlikte değerlendirilmesi amaçlandı. Çalışmamızda ağır kombine immün yetmezlik tanısı klinik bulgular ve akım sitometrik ölçümlerle konulan 30 hastanın sanger DNA dizi analizi yöntemi ile interlökin 7 reseptörü gen polimorfizmleri değerlendirildi. Total lenfosit oran ortalamasının düşüklüğü tespit edilirken lenfosit alt gruplarının değişken oranlarda olduğu görüldü. Çalışmanın sonunda ağır kombine immün yetmezlikli hastalardan birinde $(\% 3,3 ; 1 / 30)$ heterozigot p.R140Q (c.419G>A) mutasyonu tespit edilirken, hastaların 26'sinda 
$(\% 86,7 ; 26 / 30)$ de heterozigot ve/veya homozigot interlökin 7 reseptörü polimorfizmleri (T166I, I138V, T244I ve I356V) saptandı. Ağır immün yetmezlikli hastalarda interlökin 7 reseptörü gen polimorfizmlerinin sik görülmesi, bu polimorfizm ile hastalık arasında ilişki olduğu görüşünü güçlendirmiştir.

Anahtar Kelime: A Ăır Kombine Immün Yetmezlik, IL7R Polimorfizmleri, IL7R Mutasyonu

\section{Abstract}

Severe combined immunodeficiencies are a group of rare inherited disorders with profound defects in immune cells. This genetic disorder might have effect on $\mathrm{T}$ lymphocytes, B lymphocytes and/or Natural Killer cells (NK). This study aimed at the identifying the polymorphisms in interleukin 7 reseptor gene present in severe combined immunodeficies patients who located in southern part of Turkey. A total of 30 patients with severe combined immunodeficiencies that were diagnosed both clinically and by flow cytometric measurements were also investigated for interleukin 7 reseptor polymorphisms using Sanger sequencing. While the mean total lymphocytes were lower than the reference, lymphocyte subsets showed variabilities. One heterozygote p.R140Q (c.419G >A) mutation was identified in 1 patient $(n=1$, $\% 3,3)$ and $86.7 \%(\mathrm{n}=26)$ of all patients had interleukin 7 reseptor polymorphisms (T166I, I138V, T244I and I356V) whether heterozygote and/or homozygote. The frequent occurence of interleukin 7 reseptor gene polymorphisms in patients with severe immunodeficiency has strengthened the view that there is a relationship between this polymorphism and disease.

Key words: Severe Combined Immunodeficiency, IL7R Polymorphisms, IL7R Mutation

\section{Giriş}

Primer immün yetmezlik hastalıkları, kalıtsal gen defektlerine bağlı olarak, immün sistemin işleyişinde bozukluklar ile ortaya çıkan, enfeksiyonlara karşı hassasiyetin arttığı, otoimmün hastalık ve malignite oluşumuna yatkınlık ile karakterize 
hastalıklardır (Yorulmaz, Artaç, Kara, Keleş \& Reiskli, 2008; Hanımeli, Yılmaz \& Yüksel, 2010). Primer immün yetmezlik hastalıkları, ağır kombine immün yetmezlikler (SCID) ve ağır kombine immün yetmezlik olmayanlar (non-SCID) olmak üzere iki ana gruba ayrılır (Özkan, 2014). Kombine immün yetmezlik hastalıkları, kusurların özelliğine göre yalnızca $\mathrm{T}$ lenfositler $(\mathrm{T}-\mathrm{B}+\mathrm{NK}+)$, $\mathrm{T}$ lenfosit ve NK hücreleri (T-B+NK-), T ve B lenfositleri (T-B-NK+) veya $T$ ve $B$ lenfosit yanı sıra NK hücrelerini de (T-B-NK-) etkileyebilmektedir (Dincer \& Erdem, 2015).

Ağır kombine immün yetmezlik hastalığı farklı genetik nedenlere bağlı olarak ortaya çıkabilen, lenfosit fonksiyonlarında bozuklukla karakterize bir primer immün yetmezlik hastalığıdır (Derelli, Bozdoğan \& İkincioğulları, 2004). Dünya genelinde yaklaşık olarak 1/50000-1/100000 oranında canlı doğumda görülür (Kalman, Lindegren, Kobrynski, Vogt, Hannon \& Howard, 2004). Ülkemizde ise sıklığı tam olarak bilinmemekle birlikte akraba evliliğinin yoğun olması nedeniyle özellikle otozomal resesif geçiş gösteren tiplere sık rastlanmaktadır (Uygun \& Hafızoglu, 2015).

Son yıllarda ağır kombine immün yetmezlik hastalıklarına çok çeşitli genetik defektlerin neden olabileceği bildirilmekte ve hemen her yıl ağır kombine immün yetmezlik hastalığı ile ilişkili yeni bir gen defekti tanımlanmaktadır (Özkan, 2014). Ağır kombine immün yetmezlik hastalarında IL7R, CD45, IL2RG, JAK3, RAG1, RAG2, ARTEMIS ve ADA gibi genlerde defeklerin etkili olduğu düşünülmektedir (Safaei, Pourpak Moin \& Houshmand, 2011). İnterlökin 7 reseptörü (IL7R) geni 20,738 baz çifti ve sekiz ekzonu içerir. Bazı çalışmalarda $I L 7 R$ mutasyonlarının ağır kombine immün yetmezlik hastalığının nedeni olabileceği ileri sürülmüştür (Safaei, Pourpak Moin \& Houshmand, 2011). Bu çalışmada Çukurova Üniversitesi Tıbbi Genetik Anabilim Dalı ile Çocuk İmmünoloji ve Allerji Hastalıkları Bilim Dalı'na başvuran ağır kombine immün yetmezlikli hastalarda immün fenotipleme ile birlikte $I L 7 R$ polimorfizmlerini tespit etmeyi amaçlandı. 


\section{Gereç ve Yöntem}

Çalışmaya Çukurova Üniversitesi Tıp Fakültesi Tıbbi Genetik Ana Bilim Dalı ve Çocuk Allerji ve Klinik İmmünoloji Bilim Dalı'na başvuran ağır kombine immün yetmezlik hastası olan 11'i erkek 19'u k1z olmak üzere toplam 30 hasta dâhil edilmiştir. Çalışma için Çukurova Üniversitesi Tıp Fakültesi Tıp Fakültesi Girişimsel Olmayan Klinik Araştırmalar Etik Kurulundan izin alınmış ve etik kurul onaylı aydınlatılmış onam formu tüm hastalardan toplanmıştır.

Çalışma için gerekli güç analizleri ve post-hoc (çoklu karşılaştırma) testleri (Bonferroni) ClinCalc (http://clincalc.com ) kullanılarak hesaplanmıştır. Tüm istatistiksel analizler GraphPad Prism yazılımı (GraphPad Software, Inc. USA) kullanılarak gerçekleştirilmiştir. Tüm testlerde testlerde $\mathrm{p} \leq 0,05$ istatistiksel olarak anlamlı kabul edilmiştir. Her bir tespit edilen polimorfizm için Hardy-Weinberg dengesi ile değerlendirilmiştir. Polimorfizmlere ait allellerin ağır kombine immün yetmezlik ile ilişkilendirilebilmesi için majör olan allel belirlenmiş (www.varsome.com) ve referans olarak kullanılmıştır. Minör allelin, majör allele göre OR (odds ratio) değeri ve \% 95 güven aralıkları hesaplanmış, yaygın olan homozigot genotip referans olarak alınarak homozigot karşılaştırma modeli kullanılmıştır. Allel ve genotip frekansları ki-kare testi ile karşılaştırılmıştır.

Hastaların hepsinden $2 \mathrm{~mL}$ taze kan örneği alınmış, kan örneklerinin $1 \mathrm{~mL}$ 'si sanger DNA dizi analizinde geriye kalan $1 \mathrm{~mL}$ 'si ise akım sitometrede kullanılmıştır. DNA izolasyonu magnetik bead yöntemi kullanılarak otomatize DNA izolasyon sistemde yapılmıştır (Magnesia16, Anatolia Gene Works). Ağır kombine immün yetmezlik tanısı konulan hastalardaki polimorfizm taraması hedeflenen DNA bölgelerinin dizileme işlemi Sanger yöntemi (3130XL, Applied Biosystems) ile yapılmıştır. DNA dizi analizinde kullanılan primer dizileri tablo 1'de gösterilmiştir.

Akım sitometri yönteminde ise 30 hastanın 24'ü çalışmaya dâhil edilmiş, diğer 6 hasta teknik sebeplerle çalışma dışı bırakılmıştır. Tam kan lizis ve yıkama prosedürü kullanılmıştır. Kullanılan antikorlar (CD45 FITC, CD3 FITC/PERCP, CD4 FITC, CD8 PE, CD19 PE, CD16/56 PE; Becton Dickenson Bioscience) oda sicaklığına getirilerek ve temin edilen firmanın belirttiği miktarlarda çalışma tüpüne yarı 
karanlık ortamda aktarılmıştır. Periferik kan örneğinden markırların bulunduğu çalışma tüpüne $100 \mathrm{uL}$ aktarılmış, karanlıkta oda sıcaklığında 18 - 20 dakika inkübe edildikten sonra lizis solüsyonu muamele edilmiştir. Sonrasında çalışma tüpleri 300 g'de oda sıcaklığında 5 dakika santrifüj edilip, süpernatant kısmı dikkatlice alınmıştır. Çalışma tüpündeki pellet halindeki hücreler izotonik solüsyonla resüspanse edilmiştir. Resüspanse edilmiş örnekler akım sitometri cihazında (Becton Dickenson FACSCalibur) orta hızda okutularak analizleri yapılmıştır.

\section{Bulgular}

Çalışmaya dâhil edilen toplam 30 hastanın tamamı klinik ve immünofenotip olarak ağır kombine immün yetmezlik ile uyumlu olarak bulunmuştur. Yapılan akım sitometrik ölçümlerde hastaların ortalama total lenfosit yüzdelerinde, merkezimizin referans aralığına (50-83) göre düşüklük görülürken $(\mathrm{p}<0,0001)$ bunun cinsiyetler arası farklı olmadığı tespit edildi $(\mathrm{p}=0.06)$. Ancak yapılan lenfosit alt gruplarına yönelik çalışmada ise her bir hastanın değişkenlik gösterdiği gözlemlendi. Çalışmaya dâhil edilen ağır kombine immün yetmezlikli 30 hastanın 24'üne ait akım sitometri ile yapılan immün fenotipleme sonuçları tablo 2'de gösterilmektedir. (Tablo 2).

Çalışmamızda yer alan ağır kombine immün yetmezlik ön tanılı 30 hastanın 26'sında (\%86,7; 26/30) IL7R gen polimorfizmi bulundu. Hastaların 1 'inde $(\% 3,3 ; 1 / 30)$ heterozigot p.R140Q (c.419G>A) mutasyonu tespit edildi. Bu değişikliğin Mutation Taster ve PolyPhen2 veri tabanlarında hastalık sebebi olduğu görüldü. Ayrıca hastada T166I, I138V ve I356V polimorfizmlerini de heterozigot olarak taşıdığı tespit edildi. Bu değişiklikler, minör allel frekanslarının (MAF) yüksek değere sahip olması (sırasıyla T166I için \%83,3; I138V için \%83,3 ve I356V için de \%36,6) ve heterozigot olarak hastamızda bulunması nedeniyle polimorfizm olarak değerlendirildi. Çalışmaya dâhil edilen $3(\% 10,0 ; 3 / 30)$ hasta ise herhangi bir mutasyona veya polimorfizmin olmadığı tespit edildi. Hastalarda tespit edilen polimorfizmler detaylı bir şekilde tablo 3'de gösterilmektedir.

Hastalarda $I L 7 R$ geninde toplamda 16 varyant tespit edilmiş olup, bu varyantlar açısından popülasyon verileri ile karşılaştırmalar yapılmıştır. Çoklu karşılaştırma 
testlerinden Bonferroni uygulaması sonucu, tüm gen dizi analizi neticesinde elde edilen tüm polimorfizmler değerlendirmeye alındığında sağlıklı popülasyona kıyasla sadece dört polimorfizmin (T166I, I138V, T244I ve I356V) ağır kombine immün yetmezlik hastaları ile ilişkilendirilebildiği, tespit edilen diğer 12 varyant açısından ise hem genotipik hem de allel frekansları yönünden sağlıklı popülasyonla istatistiksel olarak anlamlı fark olmadığı görüldü.

Ağır kombine immün yetmezlik hastalarında tespit edilen T166I, I138V, T244I ve I356V polimorfizmlerinin dağılımları incelendiğinde; 30 hastanın 25 'inde $(\% 83,3$; 25/30) T166I, 25'inde I138V (\%83,3; 25/30), 11'inde $(\% 36,6 ; 11 / 30)$ T244I ve 11 'inde $(\% 36,6 ; 11 / 30)$ I356V polimorfizmleri tespit edildi. Polimorfizmlerin birbirleri ile olan dağılımları incelendiğinde ise ilginç olarak T166I ve I138V polimorfizmlerinin \%91,7 $(\mathrm{n}=22)$ oranında birlikte görüldüğü saptandı. T166I polimorfizminin \%16,0 (4/25)'i homozigot, \%84,0 (21/25)'i ise heterozigot olarak saptand1. I138V polimorfizmi saptanan hastaların \%28'inin (7/25) homozigot, \%72'sinin (18/25) ise heterozigot olduğu bulundu. T244I polimorfizmlerinin \%9,1'inin (1/11) homozigot, \%90,9 (10/11)'inin heterozigot olduğu belirlendi. I356V polimorfizmli hastaların \%9,1 (1/11)'inin homozigot, \%90,9 (10/11)'nin heterozigot olduğu bulundu.

\section{Tartışma}

Ağır kombine immün yetmezlikli hastalarda bakteriyel, viral, protozal ve fungal ajanlarla ağır enfeksiyonlar sık görülmekte ve hastalar immün rekonstitüsyon yapılmadığı takdirde genellikle kaybedilmektedir (Yorulmaz, Artaç, Kara, Keleş \& Reiskli, 2008). Ülkemizde ağır kombine immün yetmezlik hastalıklarının insidansı tam olarak bilinmemekle beraber akraba evliliğine bağlı olarak özellikle otozomal resesif geçiş gösteren tiplerin yüksek olduğu düşünülmektedir (Uygun \& Hafizoglu, 2015).

Moleküler ve hücresel tekniklerin gelişimine bağlı olarak ağır kombine immün yetmezliklerin bazı formlarının genetik temeli tanımlanabilmekte ve altta yatan hasara göre kemik iliği nakil rejimlerinde değişik modifikasyonlar yapılabilmektedir 
(Yorulmaz, Artaç, Kara, Keleş \& Reiskli, 2008). Dünya genelinde birçok araştırmacı ağır kombine immün yetmezlik hastalıklarının genetik özellikleri ile ilgili çeşitli araştırmalar yapmışlardır. Safaei ve ark.’1 ağır kombine immün yetmezliği olan hastalarda DNA dizi analizi yöntemini kullanarak mutasyon/polimorfizm taraması yapmışlar ve $I L 7 R$ geninde dört mutasyon, $R A G 1$ geninde 7 ve $R A G 2$ geninde de 2 mutasyon tespit etmişlerdir (Safaei, Pourpak, Moin \& Houshmand, 2011). Başka bir çalışmada da Lee ve ark.'ları ağır kombine immün yetmezlikli hastalarda $I L 2 R G$, IL7R, JAK3, RAG1, RAG2 ve DCLRE1C genlerinde mutasyonlar saptamışlardır (Lee, Chan \& Jiang, 2011).

Yu ve ark.'rı da ağır kombine immün yetmezliği olan hastalarda $I L 7 R, I L 2 R G, J A K 3$ ve CD3 T-hücre reseptör bileşenleri (CD3D-CD3E-CD3Z) genlerini araştırmışlardır (Yu, Nadeau \& Berk, 2011). Bu çalışmada $I L 7 R$ geninde hastalık yapıcı mutasyon tespit etmişler ancak diğer genlerde mutasyon tespit edememişlerdir. Butte ve ark.'ları da ağır kombine immün yetmezlikli olgularda IL7R geninde heterozigot mutasyonlar bulduklarını rapor etmişlerdir (Butte, Haines, Bonilla \& Puck, 2007). Çin'in değişik bölgelerinde ağır kombine immün yetmezlikli hastalarda mutasyon taraması yapılmış ve ülkede IL7R mutasyonun yaygın olduğu tespit edilmiştir (Tan, Yu \& Lei, 2015; Wang, Wen \& Zhen, 2014).

Bizim çalışmamızda da klinik olarak ağır kombine immün yetmezlik tanısı alan 30 hastadan birinde (hasta no:21) heterozigot p.R140Q (c.419G>A) mutasyonu tespit edilmiştir. $I L 7 R$ geni resesif karakterli olduğundan dolayı saptanan bu heterozigot değişiklik tek başına hastalığı açıklayamamaktadır. Ayrıca aynı hasta T166I, I138V ve I356V polimorfizmlerini heterozigot olarak taşımaktadır. Bu değişikliklerin MAF değeri yüksek olup polimorfizm olarak kabul edilmekle birlikte bu değişiklikleri homozigot olarak taşıyan bireylerde çeşitli enfeksiyonlara yatkınlık gibi klinik bulguların olabileceği bildirilmiştir. ClinVar (http://www.ncbi.nlm.nih.gov/clinvar/) veribankasında ise bu değişiklikler patojenik olarak belirtilmiştir. Ancak ClinVar'da bu değişiklikleri homozigot olarak taşıyanlarda gözlendiği belirtilen klinik bulgular, bizim hastamızda yapılan immün fenotipleme sonucu ile örtüşmemektedir. Hastamızda yapılan immün fenotipleme neticesinde B lenfosit yetmezliğinin ön planda olduğu görülmüştür. 
Çalışma grubumuzun \%99,3 gibi büyük çoğunluğunda sadece 4 farklı polimorfizmin segregasyon göstermesi ve bu polimorfizmlerin homozigot olduğu durumlarda literatürde ilişkilendirilmiş klinik bulguların da olması bu çalışmanın önemini ortaya koymaktadır. Çalışmamızda tespit edilen öncelikli dört polimorfizmin veribankalarında yer alan ve farklı popülasyonlara ait allel frekanslarına bakıldığında Afrika orijinlilerde \%10 - \%34, Aşkenazi Yahudileri'nde \%21 - \%27, Doğu Asya kökenlilerde $\% 6$ - \%17 ve Avrupalılarda \%26 - \%27 aralığında olduğu veribankası madenciliği neticesinde tespit edilmiştir (www.varsome.com).

Bütün bu sebeplerle, polimorfizmlerin allel dağılımlarının da değerlendirmede önemli olduğu ve bu şekilde kümelenme gösteren vakalarda klinik bulguların ortaya çıkabileceği unutulmamalıdır. Ağır kombine immün yetmezlik hastalığının epidemiyolojisinin aydınlatılması için de bu polimorfizmlerin büyük önem taşıdığı görülmektedir.

Son yıllarda geliştirilen yeni nesil dizileme yöntemlerinin kullanılmaya başlanması ağır kombine immün yetmezliklere neden olan mutasyonların tanımlanmasını daha kolay hale getirmiştir ve her geçen gün hastalığa neden olan yeni genetik defektlerin sayısı artarak literatürde yerini almakta, ilişkili genlerdeki hipomorfik mutasyonların da $\mathrm{T}$ hücre gelişimini ya da fonksiyonunu etkilemekle birlikte bir miktar hücresel gelişim ve immün yanıtın bu hastalarda olabileceği gösterilmiştir (Chou, Ohsumi \& Geha, 2012; Metzker, 2010).

Çalışmamızda ağır kombine immün yetmezlikli hastalarda $I L 7 R$ tüm gen dizi analizi yapılarak mutasyon ve polimorfizmler araştırıldı. Çalışmamız sonucunda tedavi yöntemleri için erken ve genetik tanının bu denli önemli olduğu ağır kombine immün yetmezlikli hastalarda, klinik önemi tartışılmaz olan immünfenotipleme ve genetik varyantların araştırılmasının birlikteliğinin önemi ortaya çıkmaktadır.

\section{Sonuç ve Öneriler}

Ağır kombine immün yetmezliklerin tedavisinde kullanılan hematopoetik kök hücre nakli ve gen terapisi yöntemleri için hastalığa neden olan genetik defektin bilinmesi yaşamsal önem taşımaktadır. Ağır kombine immün yetmezliğe neden olan genetik 
bozuklukların birçoğu otozomal resesif kalıtım gösterdiği için bu hastalarda akrabalık olup olmadığı saptanmalı, ailede daha önce küçük yaşta kaybedilen birey varsa araştırılmalıdır (Rivers \& Gaspar, 2014; Felgentreff, Perez-Becker \& Speckmann, 2011). Ülkemizde akraba evliliğinin sık görüldüğü özellikle Doğu ve Güney Doğu Anadolu bölgesi başta olmak üzere ölümle ile sonuçlanabilen ağır kombine immün yetmezlik hastalıklarında mutasyonların ve polimorfizmlerin gösterilmesinin büyük önemi vardır. Bu sebeple ülke genelinde immün yetmezlikle ilgili geniş genetik tanı panellerinin oluşturulması, hastalığa neden olabilecek mutasyonların ve polimorfizmlerin tespit edilmesi hastalığın erken tanısına imkân vermekten de öte tedavisine ve önlenmesine önemli ölçüde katkı sağlayacaktır. Ayrıca hasta ve aileleri içinde tespit edilen genetik etiyolojiye bağlı olarak doğru genetik danışmanlık verilebilecek, bu sayede de sadece tanı amaçlı genetik testlerin kullanımından da öte aynı zamanda prenatal tanının ve hatta preimplantasyon genetik tanının yapılabilmesi ile aileler hasta çocuk sahibi olma riskinden sakınarak sağlıklı çocuk sahibi olma şansına kavuşacaktır.

\section{Teşekkür}

Çalışmamız Çukurova Üniversitesi Bilimsel Araştırma Projeleri Koordinasyon Birimi tarafından desteklenen TSA-2016-6473 numaralı proje ile desteklenmiştir.

\section{Kaynakça}

Butte, M.J., Haines, C., Bonilla, F.A., Puck, J., (2007) IL-7 reseptor deficient SCID with a unique intronic mutation and post-transplant autoimmunity due to chronic GVHD. Clin Immunol, 125(2), 159-164.

Chou, J., Ohsumi, T.K., \& Geha, R.S., (2012) Use of whole exome and genome sequencing in the identification of genetic causes of primary immunodeficiencies. Curr Opin Allergy Clin Immunol, 12(6), 623-628.

Derelli, E., Bozdoğan, G., \& İkincioğulları, A., (2004) Ağır kombine immün yetmezlik. Sted, 13(9):349-350.

Dincer, D., Erdem, C., (2015) Primer İmmün Yetmezlik Sendromları ve Kutanöz Bulgular1. Dermatoz, 15062d1. 
Felgentreff, K., Perez-Becker, R., Speckmann, C., (2011) Clinical and immunological manifestations of patients with atypical severe combined immunodeficiency. Clin Immunol, 141(1), 73-82.

Hanımeli, Ö.A., Yılmaz, Ö., \& Yüksel, H. (2010) Primer immün yetmezlikli çocuğa Yaklaşım. Dicle Tup Dergisi, 37(3), 307-313.

Kalman, L., Lindegren, M.L., Kobrynski, L., Vogt, R., Hannon, H., \& Howard, J.T., (2004) Mutations in genes required for T-cell development: IL7R, CD45, IL2RG, JAK3, RAG1, ARTEMIS and ADA and severe combined immunodeficiency: HuGE review. Genet Med 2004; 6:16-26.

Lee, P.P., Chan, T.X., \& Jiang, L.P., (2011) Molecular diagnosis of severe combined immunodeficiency identification of IL2RG, JAK3, DCLRE1C, RAG1 and RGA2 mutations in a cohort of Chinese and Southeast sian children. J Clin Immunol, 31(2), 281-296.

Metzker, M.L., (2010) Sequencing Technologies-the next generation. Nature Reviews Genetics, 11(1): 31-46.

Özkan A., (2014) Primer immün yetmezlik hastalıkları ve hematopoetik kök hücre nakli. Arşiv Kaynak Tarama Dergisi, 23(1), 108-117.

Rivers, L., Gaspar, B., (2014) Severe combined immunodeficiency: recent developments and guidance on clinical management. Archdischild, 6.

Safaei, S., Pourpak, Z., Moin, M., \& Houshmand, M., (2011) IL7R and RAG1/2 genes mutations/polymorphisms in patients SCID. Iran J Allergy Asthma Immunol, 10(2), 129-132.

Tan, W., Yu, S., \& Lei, J., (2015) A novel common gamma chain mutation in a Chinese family with X-linked severe combined immunodeficiency X-SCID; $\mathrm{T}(-) \mathrm{NK}(-) \mathrm{B}(+)$. Immunogenetics, 67(11-12), 629-639.

Uygun, Kocacık, D.F., \& Hafizoglu, D., (2015) Primer immün yetmezlik hastalarımızın retrospektif değerlendirilmesi; Erzurum deneyimi. Asthma Allergy Immunol, 13, 90-93.

VarSome Human Genomic Variant Search Engine, www.varsome.com

Wang, X.S., Wen, P.F., \& Zhang, M., (2014) Interleukin-7 receptor single nucleotide polymorphism rs6897932 (C/T) and the susceptibility to systemic lupus erythematosus. Inflammation, 37(2), 615-620. 
Yu, G.P., Nadeau, K.C., Berk, D.R., (2011) Genotype, phenotype and outcomes of nine patients with T-B+NK+SCID. Pediatr Transplant, 15(7), 733-741.

Yorulmaz, A., Artaç, H., Kara, R., Keleş, S., \& Reiskli, İ. (2008) Primer immün yetmezlikli 1054 olgunun retrospektif değerlendirilmesi. Astım Allerji Immünoloji, 6(3), 127-134.

\begin{tabular}{|c|c|}
\hline IL7R_1F & GCTGTGTTTATACTTCCCTTGTCTGTGG \\
\hline IL7R_1R & TGCATTCCTTCTTGAGAATACTGAGGTC \\
\hline IL7R_2F & ATTTCATGTCTGCCACAGAGTCTGC \\
\hline IL7R_2R & TCTGAAAGCTGAACCGTGAGAGGAG \\
\hline IL7R_3F & CCCACCCACATACCTATGAACAGAG \\
\hline IL7R_3R & CTTTCACACCTGGGTTTGAAGATCC \\
\hline IL7R_4F & AAAGGGTCAAAGTGACTTGCAGAGG \\
\hline IL7R_4R & GAGTATGCATCAGGGAAGATCCAGG \\
\hline IL7R_5F & CTTCAGAGAATGCTTATGGGACTAAAGG \\
\hline IL7R_5R & GTTTCAACAATCTTCCTCTCACTTGCTC \\
\hline IL7R_6F & AGTAAATGCAAAGCACCCTGAGACC \\
\hline IL7R_6R & GATAGGGATACTGGGCACTAAATTCG \\
\hline IL7R_7F & ATGGTCACCCACCTAATTGTGTTAGAGC \\
\hline IL7R_7R & TTCTGGAGCTTCTGAGACACTTCAAGAC \\
\hline IL7R_8F & ССТACTCCTGAACTGAACATTTGATGG \\
\hline IL7R_8R & TTCAGAATCTTGCAGACTGTGTAGTGG \\
\hline
\end{tabular}




\begin{tabular}{|c|c|c|}
\hline \multirow[t]{2}{*}{ Hasta No } & \multicolumn{2}{|c|}{ Akım Sitometri Sonuçları (\%) } \\
\hline & Total Lenfosit & 20,3 \\
\hline \multirow{5}{*}{1} & B Lenfosit & 3,5 \\
\hline & NK & 47 \\
\hline & Total T Lenfosit & 48,7 \\
\hline & TYardımcı & 10,5 \\
\hline & T Sitotoksik & 36,21 \\
\hline \multirow{6}{*}{2} & Total Lenfosit & 24,1 \\
\hline & B Lenfosit & 18,55 \\
\hline & NK & 11,3 \\
\hline & Total T Lenfosit & 64,9 \\
\hline & TYardımcı & 7,4 \\
\hline & T Sitotoksik & 23,1 \\
\hline \multirow{6}{*}{3} & Total Lenfosit & 8,26 \\
\hline & B Lenfosit & 25,65 \\
\hline & NK & 3,9 \\
\hline & Total T Lenfosit & 62,9 \\
\hline & T Yardımcı & 39,03 \\
\hline & T Sitotoksik & 18 \\
\hline \multirow{6}{*}{4} & Total Lenfosit & 20,28 \\
\hline & B Lenfosit & 3,05 \\
\hline & NK & 16,24 \\
\hline & Total T Lenfosit & 78,2 \\
\hline & T Yardımcı & 27,1 \\
\hline & T Sitotoksik & 36,75 \\
\hline \multirow{6}{*}{5} & Total Lenfosit & 25,06 \\
\hline & B Lenfosit & 3,37 \\
\hline & NK & 46,24 \\
\hline & Total T Lenfosit & 43,9 \\
\hline & T Yardımcı & 17,52 \\
\hline & T Sitotoksik & 24,81 \\
\hline \multirow{6}{*}{6} & Total Lenfosit & 32,14 \\
\hline & B Lenfosit & 27,64 \\
\hline & NK & 0,4 \\
\hline & Total T Lenfosit & 75,3 \\
\hline & T Yardımcı & 29,9 \\
\hline & T Sitotoksik & 35,8 \\
\hline \multirow{6}{*}{7} & Total Lenfosit & 18,03 \\
\hline & B Lenfosit & 2,8 \\
\hline & NK & 12,51 \\
\hline & Total T Lenfosit & 77,2 \\
\hline & T Yardımcı & 23,9 \\
\hline & T Sitotoksik & 52,5 \\
\hline \multirow{6}{*}{8} & Total Lenfosit & 59 \\
\hline & B Lenfosit & 16,08 \\
\hline & NK & 8,25 \\
\hline & Total T Lenfosit & 73,9 \\
\hline & TYardımcı & 30,84 \\
\hline & T Sitotoksik & 40,4 \\
\hline
\end{tabular}

\begin{tabular}{|c|c|c|}
\hline Hasta No & Akım Sitometri & cları (\%) \\
\hline \multirow{6}{*}{9} & Total Lenfosit & 18,26 \\
\hline & B Lenfosit & 31,33 \\
\hline & NK & 1,4 \\
\hline & Total T Lenfosit & 56,9 \\
\hline & T Yardımcı & 24,72 \\
\hline & T Sitotoksik & 23,62 \\
\hline \multirow{6}{*}{10} & Total Lenfosit & 7,22 \\
\hline & B Lenfosit & 16,41 \\
\hline & NK & 7,2 \\
\hline & Total T Lenfosit & 67,2 \\
\hline & T Yardımcı & 36,8 \\
\hline & T Sitotoksik & 25,3 \\
\hline \multirow{6}{*}{11} & Total Lenfosit & 19,39 \\
\hline & B Lenfosit & 29,76 \\
\hline & NK & 13,5 \\
\hline & Total T Lenfosit & 53,8 \\
\hline & T Yardımcı & 29,93 \\
\hline & T Sitotoksik & 21,21 \\
\hline \multirow{6}{*}{12} & Total Lenfosit & 12,17 \\
\hline & B Lenfosit & 60,04 \\
\hline & NK & 25,02 \\
\hline & Total T Lenfosit & 7,5 \\
\hline & T Yardımcı & 1,7 \\
\hline & T Sitotoksik & 4,5 \\
\hline \multirow{6}{*}{13} & Total Lenfosit & 49,56 \\
\hline & B Lenfosit & 13,1 \\
\hline & NK & 8,62 \\
\hline & Total T Lenfosit & 69 \\
\hline & T Yardımcı & 23,26 \\
\hline & T Sitotoksik & 47,9 \\
\hline \multirow{6}{*}{14} & Total Lenfosit & 61,02 \\
\hline & B Lenfosit & 22,2 \\
\hline & NK & 5,8 \\
\hline & Total T Lenfosit & 69,7 \\
\hline & T Yardımcı & 47,14 \\
\hline & T Sitotoksik & 20,2 \\
\hline \multirow{6}{*}{15} & Total Lenfosit & 2,07 \\
\hline & B Lenfosit & 2,7 \\
\hline & NK & 76,7 \\
\hline & Total T Lenfosit & 11,15 \\
\hline & T Yardımcı & 4,14 \\
\hline & T Sitotoksik & 6,7 \\
\hline \multirow{6}{*}{16} & Total Lenfosit & 14,47 \\
\hline & B Lenfosit & 0,64 \\
\hline & NK & 79,45 \\
\hline & Total T Lenfosit & 5,9 \\
\hline & T Yardımcı & 1,3 \\
\hline & T Sitotoksik & 2,12 \\
\hline
\end{tabular}

\begin{tabular}{|c|c|c|}
\hline \multirow[t]{2}{*}{ Hasta No } & \multicolumn{2}{|c|}{ Akım Sitometri Sonuçları (\%) } \\
\hline & Total Lenfosit & 41,46 \\
\hline \multirow{5}{*}{17} & B Lenfosit & 67,89 \\
\hline & NK & 1,04 \\
\hline & Total T Lenfosit & 27,8 \\
\hline & T Yardımcı & 4,9 \\
\hline & T Sitotoksik & 21,24 \\
\hline \multirow{6}{*}{18} & Total Lenfosit & 48,1 \\
\hline & B Lenfosit & 8,02 \\
\hline & NK & 79,9 \\
\hline & Total T Lenfosit & 8,7 \\
\hline & T Yardımcı & 4,13 \\
\hline & T Sitotoksik & 3,5 \\
\hline \multirow{6}{*}{19} & Total Lenfosit & 1,6 \\
\hline & B Lenfosit & 30,8 \\
\hline & NK & 51,9 \\
\hline & Total T Lenfosit & 4,46 \\
\hline & T Yardımcı & 3,15 \\
\hline & T Sitotoksik & 0,56 \\
\hline \multirow{6}{*}{20} & Total Lenfosit & 30,71 \\
\hline & B Lenfosit & 53,26 \\
\hline & NK & 10,13 \\
\hline & Total T Lenfosit & 30,75 \\
\hline & T Yardımcı & 19,31 \\
\hline & T Sitotoksik & 10,31 \\
\hline \multirow{6}{*}{21} & Total Lenfosit & 21,17 \\
\hline & B Lenfosit & 2,3 \\
\hline & NK & 82 \\
\hline & Total T Lenfosit & 9,92 \\
\hline & T Yardımcı & 5,64 \\
\hline & T Sitotoksik & 4,14 \\
\hline \multirow{6}{*}{22} & Total Lenfosit & 51,92 \\
\hline & B Lenfosit & 21 \\
\hline & NK & 56 \\
\hline & Total T Lenfosit & 16,9 \\
\hline & T Yardımcı & 6,46 \\
\hline & T Sitotoksik & 10,2 \\
\hline \multirow{6}{*}{23} & Total Lenfosit & 15,04 \\
\hline & B Lenfosit & 0,9 \\
\hline & NK & 6,44 \\
\hline & Total T Lenfosit & 83,28 \\
\hline & T Yardımcı & 30,49 \\
\hline & T Sitotoksik & 51,87 \\
\hline \multirow{6}{*}{24} & Total Lenfosit & 5,8 \\
\hline & B Lenfosit & 79,3 \\
\hline & NK & 2,43 \\
\hline & Total T Lenfosit & 4,9 \\
\hline & TYardımcı & 3,8 \\
\hline & T Sitotoksik & 0,5 \\
\hline
\end{tabular}

Tablo 2: Kombine Ăgır İmmün Yetmezlikli Hastalarda Akım Sitometri ile Yapılan İmmün Fenotipleme Sonuçları, İmmün Hücre Grupları Yüzdeleri Şeklinde Sunulmuştur. 


\begin{tabular}{|c|c|c|c|c|}
\hline \multirow{2}{*}{$\begin{array}{l}\text { Hasta } \\
\text { No }\end{array}$} & \multicolumn{4}{|c|}{ POLIMMORFİM } \\
\hline & T166I & I138V & T244I & I356V \\
\hline 1 & Homozigot & Homozigot & Heterozigot & Heterozigot \\
\hline 2 & Heterozigot & Heterozigot & Heterozigot & - \\
\hline 3 & Heterozigot & Homozigot & - & Heterozigot \\
\hline 4 & Heterozigot & Heterozigot & Heterozigot & - \\
\hline 5 & Homozigot & Homozigot & Homozigot & - \\
\hline 6 & Heterozigot & Heterozigot & Heterozigot & - \\
\hline 7 & Heterozigot & Heterozigot & - & Heterozigot \\
\hline 8 & Heterozigot & Heterozigot & - & - \\
\hline 9 & - & - & - & - \\
\hline 10 & Heterozigot & Heterozigot & - & - \\
\hline 11 & Heterozigot & Heterozigot & - & - \\
\hline 12 & - & Homozigot & - & - \\
\hline 13 & Heterozigot & Heterozigot & - & - \\
\hline 14 & Heterozigot & Homozigot & - & Heterozigot \\
\hline 15 & Heterozigot & Heterozigot & - & - \\
\hline 16 & Homozigot & Homozigot & Heterozigot & Heterozigot \\
\hline 17 & - & - & - & - \\
\hline 18 & Heterozigot & Heterozigot & Heterozigot & - \\
\hline 19 & Heterozigot & - & Heterozigot & - \\
\hline 20 & Heterozigot & Heterozigot & - & Heterozigot \\
\hline 21 & Heterozigot & Heterozigot & - & Heterozigot \\
\hline 22 & Heterozigot & Heterozigot & - & Heterozigot \\
\hline 23 & Heterozigot & Heterozigot & - & Heterozigot \\
\hline 24 & - & - & - & - \\
\hline 25 & Heterozigot & Heterozigot & Heterozigot & - \\
\hline 26 & Heterozigot & Heterozigot & Heterozigot & - \\
\hline 27 & Heterozigot & Heterozigot & - & Heterozigot \\
\hline 28 & Heterozigot & Heterozigot & Heterozigot & - \\
\hline 29 & - & - & - & - \\
\hline 30 & Homozigot & Homozigot & - & Homozigot \\
\hline
\end{tabular}

Tablo 3: Interlökin 7 reseptörü (IL7R) Gen Polimorfizmleri. 21 Nolu Hastada Polimorfizmlere Ek Olarak Heterozigot p.R140Q (c.419G>A) Mutasyonu Tespit Edilmiştir. 